\title{
Analisis Perkembangan Bisnis Online Mahasiswa Karawang Menggunakan Metode Customer Satisfaction Index (CSI)
}

Online Business Development Analysis of Karawang University Students Using Customer Satisfaction Index Method (CSI)

\author{
Hannie*1, Dini Sri Istiningdias $^{2}$, Ultach Enri $^{3}$ \\ ${ }^{1,2,3}$ Sistem Informasi; Universitas Singaperbangsa Karawang \\ 1, 2, 3 Karawang, Indonesia \\ e-mail: *1hannie@staff.unsika.ac.id, 2dinisriistiningdias@ staff.unsika.ac.id, \\ 3ultach@staff.unsika.ac.id
}

\begin{abstract}
Abstrak - Saat ini banyak mahasiswa melakukan usaha bisnis pada masa perkuliahan. Masa kuliah adalah masa yang tepat bagi mahasiswa untuk memulai usaha bisnis karena mahasiswa dapat belajar langsung menghadapi tantangan dunia kerja. Berbekal kreativitas, peluang dan keberanian dalam mengambil resiko maka mahasiswa dapat melakukan usaha bisnis online untuk memasarkan produknya lebih luas. Analisis yang dilakukan pada penelitian ini bertujuan untuk mengukur perkembangan bisnis online di kalangan mahasiswa Universitas Singaperbangsa Karawang. Atribut pelayanan jasa dapat dijadikan masukkan dalam meningkatkan bisnis online mahasiswa dengan menggunakan metode Customer Satisfaction Index (CSI). Penelitian dilakukan di Universitas Singaperbangsa Karawang. Data penelitian diperoleh dari kuesioner yang dibagikan secara online menggunakan Google Form. Metode pengambilan sample yang digunakan yaitu metode nonprobability sampling dengan jenis purposive sampling, dimana teknik penentuan sampel berdasarkan kriteria yaitu mahasiswa Universitas Singaperbangsa Karawang dan mempunyai usaha bisnis. Uji pengolahan data menggunakan Uji Validitas dan Uji Realibilitas. Perhitungan Customer Satisfaction Index menunjukkan hasil sebesar 74,49\%. Hasil tingkat kepuasan diantara $66 \%$ - $80 \%$ menunjukkan bahwa mahasiswa puas dengan perkembangan bisnis online.
\end{abstract}

Kata kunci - Bisnis online, Customer Satisfaction Index, Mahasiswa, Universitas Singaperbangsa Karawang

Abstract - Currently, many students build business during their studies period in college. College period is the right time for students to start a business because students can learn directly to face the work challenges. By creativity, opportunity and courage in taking risks then students can conduct online business to market their products more widely. The analysis carried out in this research aimed to determine the development of online business among Universitas Singaperbangsa Karawang students. Service attributes can be used as input in improving student's online business by using the Customer Satisfaction Index (CSI) method. The research was conducted at Universitas Singaperbangsa Karawang. The research data were obtained from questionnaires distributed online using Google Form. The sampling method used was nonprobability sampling method with purposive sampling type, where the sampling technique was based on the criteria, such as Universitas Singaperbangsa Karawang students and having a business. Test data processing used the validity test and reliability test. The calculation of the Customer Satisfaction Index showed a result of 74.49\%. The results of the satisfaction level between $66 \%$ - 80\% indicated that students are satisfied with the development of an online business.

Keywords - Online Business, Customer Satisfaction Index, University Students, Universitas Singaperbangsa Karawang 


\section{PENDAHULUAN}

Bisnis Online adalah kegiatan bisnis baik jasa maupun produk yang dilakukan secara online menggunakan media internet. Penggunaan media internet berkembang dengan cepat dan menjadi bagian terpenting dalam memenuhi kebutuhan manusia yang secara perlahan telah mengubah pola gaya hidup dan pola pemikiran masyarakat. Berdasarkan hasil survey dari APJII pada tahun 2018 bahwa wilayah Pulau Jawa paling banyak yang menggunakan internet yaitu sebesar 55,7 \% [1]. Sementara itu, Universitas Singaperbangsa Karawang sebagai lokasi penelitian terletak di Kabupaten Karawang Provinsi Jawa Barat, Indonesia.

Universitas Singaperbangsa Karawang merupakan perguruan tinggi negeri yang memiliki 9 fakultas dan 32 program studi, dimana setiap tahun selalu meningkat jumlah mahasiswanya. Lokasi Universitas Singaperbangsa Karawang sangat strategis untuk dijadikan tempat berbisnis karena merupakan kawasan industri. Setiap tahun jumlah penduduk di Kabupaten Karawang selalu meningkat berdasarkan data Badan Pusat Statistik (BPS) [2]. Hal tersebut mengakibatkan kondisi lalu lintas di Kabupaten Karawang menjadi sangat padat dan perjalanan ke lokasi perbelanjaan untuk membutuhkan waktu yang lama. Selain itu, saat ini sedang terjadi pandemi COVID-19 dimana warga dilarang untuk berpergian agar dapat mencegah dan mengurangi penyebaran virus corona. Peluang tersebut menjadi target untuk berbisnis bagi mahasiswa. Masa kuliah adalah masa yang tepat bagi mahasiswa untuk memulai bisnis karena mahasiswa dapat belajar langsung menghadapi tantangan dunia kerja. Berbekal kreativitas, peluang dan keberanian mengambil resiko maka mahasiswa dapat melakukan usaha bisnis online.

Ada berbagai macam usaha bisnis yang telah dilakukan oleh mahasiswa Universitas Singaperbangsa Karawang dalam menjalankan usaha bisnis seperti jualan makanan, pakaian, tas, buku dan lainnya. Namun, proses pemasaran produk sebagian mahasiswa masih menjalankan metode konvensional (offline) dan menggunakan social media atau whatsapp sehingga kurang maksimal dalam aktivitas pemasaran produk, peningkatan pendapatan dan kepercayaan konsumen kepada penjual ketika melakukan transaksi pembelian barang.
Keuntungan menjalankan bisnis online lebih menjanjikan daripada peluang usaha offline. Bisnis online tidak harus mempunyai toko fisik, pemasaran lebih luas, durasi waktu berjualan 24 jam, dan dapat memulai bisnis dengan modal yang minimum melalui marketplace. Marketplace adalah sebuah situs atau aplikasi online yang bertindak sebagai pihak ketiga dalam proses transaksi jual beli online dari berbagai macam toko.

Tujuan penelitian ini yaitu untuk mengukur tingkat kepuasan mahasiswa sebagai upaya meningkatkan kualitas layanan bisnis online mahasiswa. Kepuasan mahasiswa diukur dengan menggunakan metode Customer Satisfaction Index (CSI). CSI merupakan indeks untuk menentukan tingkat kepuasan pelanggan secara menyeluruh dengan pendekatan yang mempertimbangkan tingkat kepentingan dari atribut produk atau jasa [3]. Sedangkan untuk membantu mahasiswa dalam menentukan atribut pelayanan produk atau jasa yang dibutuhkan mahasiswa dalam memasarkan bisnis secara online dan atribut pelayanan yang perlu diperbaiki dengan cara menggunakan metode Importance Performance Analysis (IPA). Metode SERQUAL IF dan IPA mampu menjelaskan sejumlah besar kualitas layanan pada saat yang sama, factor kualitas layanan model IPA memiliki pertimbangan yang lebih komprehensif dibandingkan SERQUAL IF [4]. Dikarenakan Importance Performance Analysis merupakan suatu teknik analisis yang digunakan untuk mengidentifikasi faktorfaktor kinerja penting apa saja yang harus ditunjukkan oleh suatu organisasi dalam memenuhi kepuasan para pengguna jasa (konsumen) [5].

Adanya urgensi penelitian dikarenakan kurangnya pemahaman mahasiswa tentang cara berbisnis online, ketidakmampuan mahasiswa dalam menghadapi dunia kerja setelah lulus kuliah, rendahnya minat atau motivasi mahasiswa untuk membuka lapangan kerja atau membuka usaha setelah lulus kuliah dan belum ada sebuah website atau aplikasi penjualan online yang disediakan Universitas untuk memasarkan produk mahasiswa, dimana yang kedepannya sangat bermanfaat dalam meningkatkan kualitas mahasiswa dan Universitas. 


\section{LANDASAN TEORI}

\subsection{Bisnis Online}

Bisnis adalah kegiatan yang dilakukan oleh individu dan sekelompok orang (organisasi) yang menciptakan nilai (create value) melalui penciptaan barang dan jasa (create of good and service) untuk memenuhi kebutuhan masyarakat dan memperoleh keuntungan melalui transaksi [6].

Online berarti segala aktivitas yang menggunakan internet dimana kita bisa berkomunikasi atau berhubungan atau terkoneksi dengan banyak orang melalui dunia maya. Secara umum, sesuatu dikatakan online adalah bila interkoneksi/terhubung dalam suatu jaringan ataupun sistem yang lebih besar [7].

Bisnis online didefenisikan sebagai kegiatan menjual barang / jasa untuk mendapatkan keuntungan melalui media internet [7].

\subsection{Lapangan Pekerjaan}

Tenaga kerja (man power) merupakan seluruh penduduk yang dianggap memiliki potensi untuk bekerja secara produktif [8]. Di Indonesia kesempatan kerja dijamin dalam UUD 1945 pasal 27 ayat 2 yang berbunyi "Tiap-tiap warga Negara berhak atas pekerjaan dan penghidupan yang layak". Dari bunyi UUD 1945 pasal 27 ayat 2 itu jelas bahwa pemerintah Indonesia untuk menciptakan lapangan kerja bagi anggota masyarakat karena hal ini berhubungan dengan usaha masyarakat untuk mendapat penghasilan.

\subsection{Kualitas Pelayanan}

Kualitas pelayanan merupakan segala sesuatu yang memfokuskan pada usaha-usaha memenuhi kebutuhan dan keinginan para konsumen yang disertai dengan ketepatan dalam menyampaikannya sehingga tercipta kesesuaian yang seimbang dengan harapan konsumen [9].

\subsection{Teknik Sampling}

Teknik Sampling adalah merupakan teknik pengambilan sampel. Untuk menentukan sampel yang akan digunakan dalam penelitian. Ada 2 macam teknik pengambilan sampling [10] yaitu :
1. Probability Sampling adalah teknik sampling untuk memberikan peluang yang sama pada setiap anggota populasi untuk dapat menjadi anggota sampel.

2. Non-Probability Sampling adalah teknik pengambilan sampel yang tidak memberikan kesempatan (peluang) yang sama bagi setiap unsur atau anggota populasi untuk dipilih menjadi sampel.

a. Purposive Sampling adalah teknik penentuan sampel dengan pertimbangan atau kriteria-kriteria tertentu.

\subsection{Validitas dan Reliabitas Instrumen}

Validitas dan Reliabitas digunakan sebagai panduan dalam membuat kuesioner. Data penelitian menggunakan dengan cara membagikan kuesioner ke mahasiswa Universitas Singaperbangsa secara online. Untuk melakukan uji Validitas dan Reliabitas menggunakan bantuan SPSS versi 23 for windows.

1. Uji validitas digunakan untuk mengetahui kelayakan butir-butir dalam suatu daftar pertanyaan dalam mendefinisikan suatu variable. Daftar pertanyaan pada umumnya mendukung suatu kelompok variable tertentu.

Teknik yang dipakai yaitu rumus teknik korelasi Pearson product moment sebagai berikut [11] :

$$
r \text { hitung }=\frac{\mathrm{n} \Sigma \mathrm{XY}-\Sigma \mathrm{X} \Sigma y}{\sqrt{\mathrm{n} \Sigma \mathrm{X}^{2}-(\Sigma \mathrm{X})^{2}}-\sqrt{\mathrm{n} \Sigma \mathrm{Y}^{2}-(\Sigma \mathrm{Y})^{2}}}
$$

Dimana :

$$
\begin{array}{ll}
\mathrm{r}_{\text {hitung }} & =\text { Koefisien Korelasi } \\
\mathrm{n} & =\text { Jumlah responden } \\
\mathrm{X} & =\text { Skor tiap pertanyaan } \\
\mathrm{Y} & =\text { Skor total }
\end{array}
$$

Hasil $r$ hitung dibandingkan dengan $r$ table, Jika $r$ hitung $>r$ table maka hasilnya valid. Mencari nilai $r$ table dengan cara :

$$
\mathrm{d}(\mathrm{f})=\mathrm{n}-2 \ldots(2)
$$

Dimana :

$\mathrm{d}(\mathrm{f})=$ Degree of freedom

Alpha $=5 \%$ 
2. Uji realibilitas merupakan ukuran suatu kestabilan dan konsistensi responden dalam menjawab hal yang berkaitan dengan isi pertanyaan yang merupakan dimensi suatu variable dan disusun dalam suatu bentuk kuisioner. Realibilitas mencakup dua hal utama yaitu stabilitas ukuran dan konsistensi internal. Jika nilai Cronbach Alpha > 0,60 maka reliabel. Dengan rumus sebagai berikut [12] :

$$
r=\left[\frac{\mathrm{k}}{(k-1)}\right]\left[1-\frac{\Sigma{\sigma_{b}}^{2}}{\sigma_{t}^{2}}\right] .
$$

Dimana :

$\mathrm{r} \quad=$ koefisien reliability instrument (Cronbach Alfa)

$\mathrm{k}=$ Banyaknya butir pertanyaan

$\Sigma \sigma_{b}^{2}=$ Total Varians butir

$\sigma_{t}{ }^{2}=$ Total Varians

\subsection{Importance Performance Analysis}

Importance Performance Analysis dibuat atas hasil tabulasi kuesioner. Martilla dan Jams, menyarankan metode Importance Performance Analysis dalam mengukur tingkat kepuasan pelayanan jasa [9]. Dimana ada 4 kuadran untuk seluruh variable yang mempengaruhi kualitas pelayanan, yaitu Concentrate these, Keep Up The Good Work, Low Priority dan Possible Overkil

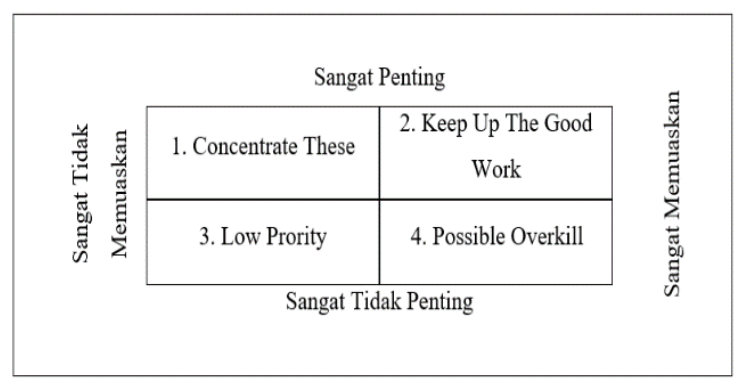

Gambar 1. Peta Importance Performance [9]

\subsection{Customer Satisfaction Index}

Customer Satisfaction Index digunakan untuk mengukur tingkat kepuasan konsumen Karawang terhadap kinerja pelayanan penjualan online. Untuk mengetahui besarnya CSI, maka dapat dilakukan langkah-langkah sebagai berikut [13] :

1. Menentukan Mean Importance Score (MIS) tiap-tiap variabel.
2. Membuat Weight Factors (WF) per variabel. Bobot ini merupakan persentase nilai $M I S$ per variabel terhadap total $M I S$ seluruh variabel.

3. Menentukan Mean Satisfaction Score (MSS) tiap atribut.

4. Membuat Weight Score (WSk) tiap variabel. Bobot ini merupakan perkalian antara WFk dengan MSSk

5. Menentukan Customer Satisfaction Index (CSI)

\section{METODE}

Berikut Tahapan Penelitian yang digunakan :

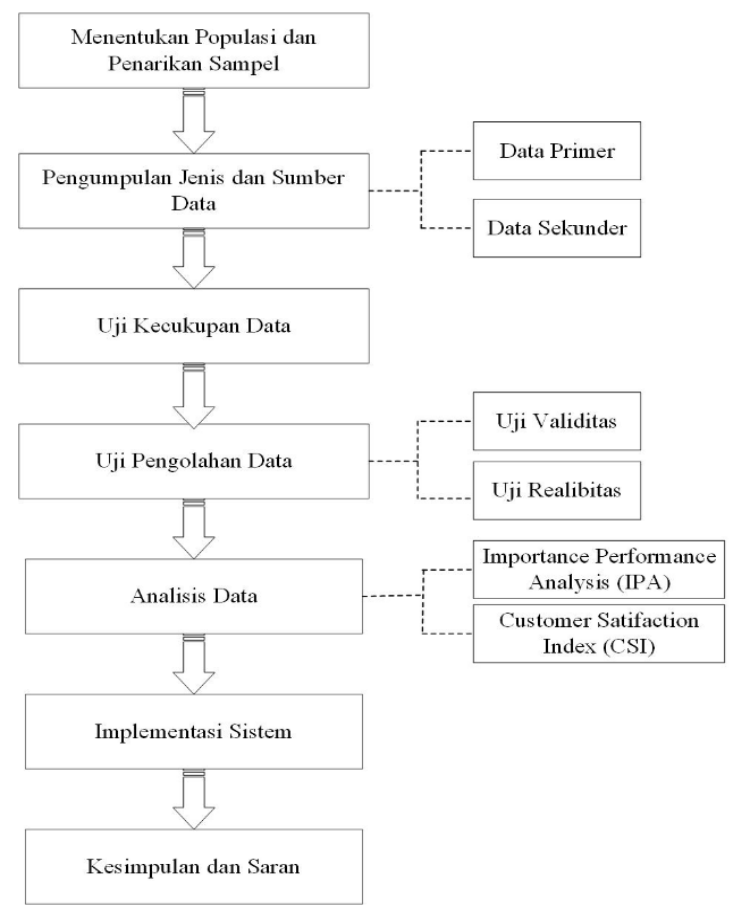

Gambar 2. Alur Penelitian

\subsection{Menentukan Populasi dan Penarikan Sampel}

Penelitian di Universitas Singaperbangsa Karawang, dimana populasi yang diteliti yaitu mahasiswa. Metode Penarikan sample penelitian dilakukan dengan metode non probability sampling, dengan pendekatan purposive sampling dimana teknik penentuan sampel berdasarkan kriteria yaitu mahasiswa Universitas Singaperbangsa Karawang dan mempunyai usaha bisnis [14]. 


\subsection{Pengumpulan Jenis dan Sumber Data}

Data yang digunakan dalam penelitian ini yaitu pengumpulan data yang berupa :

1. Data Primer yang diperoleh melalui hasil penelitian langsung terhadap obyek yang diteliti. Data tersebut diperoleh dari kuesioner yang dibagikan secara online ke mahasiswa Universitas Singaperbangsa Karawang.

2. Data Sekunder merupakan data penting dan bermanfaat untuk mendukung informasi penelitian yang diperoleh dari perpustakaan, makalah, artikel, internet dan pihak internal. Data sekunder yang didapatkan berupa data kuantitatif dan data kualitatif.

\subsection{Uji Kecukupan Data}

Sampel adalah bagian dari jumlah dan karakteristik yang dimiliki oleh populasi [10]. Untuk menentukan besarnya jumlah responden yang akan digunakan dalam penelitian adalah dengan menggunakan rumus 25 kali variable bebas [15]. Dimana variabel bebas (X) yaitu service (X1), Assurance (X2), dan Tangibles (X3).

\subsection{Uji Pengolahan Data}

1. Uji Validitas

Setelah kuesioner akhir terbentuk, langkah selanjutnya adalah melakukan uji validitas dengan bantuan aplikasi SPSS versi 23 for windows. Atribut pertanyaan dinyatakan valid bila $r$ hitung $>r$ tabel.

2. Uji Realibilitas

Uji reliabilitas (keandalan) untuk mengukur kestabilan dan konsistensi responden dalam menjawab hal yang berkaitan dengan bisnis online kemudian diolah menggunakan aplikasi SPSS dengan cara menguji nilai Cronbach Aplha.

\subsection{Analisis Data}

\section{Importance Performance Analysis}

Dalam menganalisis data penelitian ini digunakan metode Importance Performance. Untuk menjawab perumusan masalah mengenai tingkat kepuasan Mahasiswa Karawang terhadap perkembangan bisnis online. Analisis tingkat kepentingan dan tingkat kinerja ini diukur dengan menggunakan skala Likert 5 tingkat untuk mengukur sikap, pendapat dan persepsi seseorang atau sekelompok tentang kejadian atau gejala sosial.

Tabel 1. Nilai menurut tingkat kepentingan dan tingkat kinerja [10]

\begin{tabular}{ccc}
\hline $\begin{array}{c}\text { Skor } / \\
\text { Nilai }\end{array}$ & $\begin{array}{c}\text { Tingkat } \\
\text { Kepentingan }\end{array}$ & $\begin{array}{c}\text { Tingkat } \\
\text { Kinerja }\end{array}$ \\
\hline 1 & Sangat Tidak & Sangat Tidak \\
2 & Penting & Baik \\
3 & Tidak Penting & Tidak Baik \\
4 & Biasa & Biasa \\
5 & Penting & Baik \\
Sangat Penting & Sangat Baik \\
\hline
\end{tabular}

\section{Customer Satisfaction Index}

Customer Satisfaction Index digunakan untuk menentukan tingkat kepuasan Mahasiswa Karawang dalam bisnis online secara menyeluruh dengan pendekatan yang mempertimbangkan tingkat harapan dari atribut-atribut kualitas jasa yang diukur dalam menentukan sasaran di tahun mendatang. Tanpa adanya CSI mustahil top management dapat menentukan goal dalam perkembangan bisnis online, dan indeks diperlukan karena proses pengukuran kepuasan mahasiswa bersifat kontinyu.

Tabel 2. Kriteria kepuasan konsumen [16]

\begin{tabular}{ccc}
\hline No & $\begin{array}{c}\text { Nilai } \\
\text { IKP }\end{array}$ & $\begin{array}{c}\text { Indeks } \\
\text { Kepuasan } \\
\text { Pelanggan }\end{array}$ \\
\hline 1 & $81-100$ & Sangat Puas \\
2 & $66-80$ & Puas \\
3 & $51-65$ & Cukup Puas \\
4 & $35-50$ & Kurang Puas \\
5 & $0-34$ & Tidak Puas \\
\hline
\end{tabular}

\section{HASIL DAN PEMBAHASAN}

\subsection{Uji Kecukupan Data}

Data penelitian didapat dengan cara membagikan kuesioner secara online kepada mahasiswa Universitas Singaperbangsa Karawang. Kuesioener menggunakan Google Form mulai dari 1 - 28 September 2020 dan yang mengisi kuesioner sebanyak 376 responden. Namun, data yang digunakan untuk penelitian hanya 75 responden berdasarkan :

1. Purposive Sampling, dimana teknik penentuan sampel berdasarkan kriteria yaitu mahasiswa Universitas Singaperbangsa Karawang dan mempunyai usaha bisnis. 


\begin{tabular}{|c|c|c|}
\hline \multicolumn{3}{|c|}{$\begin{array}{l}\text { Tabel 3. Data Mahasiswa yang Mengisi } \\
\text { Kuesioner }\end{array}$} \\
\hline Data & $\begin{array}{l}\text { Responden } \\
\text { (Mahasiswa) }\end{array}$ & $\begin{array}{c}\text { Persentase } \\
(\%)\end{array}$ \\
\hline $\begin{array}{l}\text { Mahasiswa yang } \\
\text { tidak mempunyai } \\
\text { Bisnis }\end{array}$ & 298 & 79 \\
\hline $\begin{array}{l}\text { Mahasiswa Yang } \\
\text { mempunyai Bisnis }\end{array}$ & 78 & 21 \\
\hline Jumlah & 376 & 100 \\
\hline
\end{tabular}

Berdasarkan hasil dari survey 75 mahasiswa pada tabel 4 bahwa masih ada mahasiswa yang berjualan secara offline yaitu sekitar $24 \%$.

Tabel 4. Jenis Toko

\begin{tabular}{lcc}
\hline Jenis Toko & $\begin{array}{l}\text { Responden } \\
\text { (mahasiswa) }\end{array}$ & $\begin{array}{l}\text { Persentase } \\
(\boldsymbol{\%})\end{array}$ \\
\hline Toko Offline & 18 & 24 \\
Toko Online & 52 & 69 \\
Toko Offline & & 7 \\
\& Online & 5 & 100 \\
\hline Jumlah & 75 & \\
\hline
\end{tabular}

2. Rumus $=25 \mathrm{x}$ variable bebas [15].

$$
\begin{aligned}
& =25 \times \text { variable bebas } \\
& =25 \times 3 \text { (jumlah variable bebas) } \\
& =75 \text { responden }
\end{aligned}
$$

\subsection{Uji Validitas}

Hasil Uji Validitas indicator Tingkat harapan, Tingkat kepentingan dan Tingkat kinerja menggunakan SPSS versi 23 for windows. Dari hasil Uji Validitas tingkat harapan, tingkat kepentingan dan tingkat kinerja bahwa $r$ hitung atau Corrected ItemTotal Correlation $>\mathrm{r}$ table. Dimana $\mathrm{r}$ table yaitu 0,1914. Sehingga semua pertanyaan variable tingkat harapan, tingkat kepentingan dan tingkat kinerja dinyatakan valid

Tabel 5. Hasil Uji Validitas Indikator Tingkat Harapan, Kepentingan dan Kinerja

\begin{tabular}{ccccc}
\hline $\begin{array}{c}\text { Per } \\
\text { Tanya } \\
\text { an }\end{array}$ & $\begin{array}{c}\text { Tingkat } \\
\text { Hara } \\
\text { pan }\end{array}$ & $\begin{array}{c}\text { Tingkat } \\
\text { Kepenti } \\
\text { ngan }\end{array}$ & $\begin{array}{c}\text { Tingkat } \\
\text { Kinerja }\end{array}$ & Ket \\
\cline { 2 - 4 } & r hitung & r hitung & r hitung & \\
\hline Butir 1 & 0.577 & 0.641 & 0.579 & Valid \\
\hline Butir 2 & 0.697 & 0.737 & 0.737 & Valid \\
\hline Butir 3 & 0.766 & 0.618 & 0.708 & Valid \\
\hline Butir 4 & 0.836 & 0.834 & 0.843 & Valid \\
\hline Butir 5 & 0.752 & 0.795 & 0.685 & Valid \\
\hline Butir 6 & 0.893 & 0.888 & 0.875 & Valid \\
\hline Butir 7 & 0.830 & 0.811 & 0.752 & Valid \\
\hline Butir 8 & 0.728 & 0.719 & 0.665 & Valid \\
\hline Butir 9 & 0.817 & 0.831 & 0.750 & Valid \\
\hline Butir & 0.718 & 0.728 & 0.674 & Valid \\
\hline
\end{tabular}

\begin{tabular}{ccccc}
\hline $\begin{array}{c}\text { Per } \\
\text { Tanya } \\
\text { an }\end{array}$ & $\begin{array}{c}\text { Tingkat } \\
\text { Hara } \\
\text { pan }\end{array}$ & $\begin{array}{c}\text { Tingkat } \\
\text { Kepenti } \\
\text { ngan }\end{array}$ & $\begin{array}{c}\text { Tingkat } \\
\text { Kinerja }\end{array}$ & Ket \\
\cline { 2 - 4 } r hitung & r hitung & r hitung & \\
\hline 10 & & & & \\
\hline $\begin{array}{c}\text { Butir } \\
11\end{array}$ & 0.612 & 0.570 & 0.528 & Valid \\
\hline $\begin{array}{c}\text { Butir } \\
12\end{array}$ & 0.819 & 0.834 & 0.772 & Valid \\
\hline $\begin{array}{c}\text { Butir } \\
13\end{array}$ & 0.813 & 0.827 & 0.785 & Valid \\
\hline $\begin{array}{c}\text { Butir } \\
14\end{array}$ & 0.827 & 0.815 & 0.784 & Valid \\
\hline $\begin{array}{c}\text { Butir } \\
15\end{array}$ & 0.691 & 0.600 & 0.682 & Valid \\
\hline
\end{tabular}

\subsection{Uji Reliabilitas}

Hasil uji reliabilitas tiap-tiap pertanyaan pada item kuesioner Tingkat Harapan, Tingkat Kepentingan dan Tingkat Kinerja dengan menggunakan aplikasi SPSS versi 23 for windows menyatakan reliabel. Dikarenakan Cronbach's Aplha tingkat harapan, tingkat kepentingan dan tingkat kinerja > 0,60.

Tabel 6. Hasil Uji Reliabilitas Indikator Tingkat Harapan, Kepentingan dan Kinerja Hasil Uji Reliabilitas

\begin{tabular}{l|r|c|r|}
\hline Tingkat & \multicolumn{3}{c|}{ Reliability Statistics } \\
\cline { 2 - 4 } Harapan & $\begin{array}{c}\text { Cronbach's } \\
\text { Alpha Based } \\
\text { on } \\
\text { On } \\
\text { Cronbach's } \\
\text { Alpha }\end{array}$ & $\begin{array}{c}\text { Standardized } \\
\text { Items }\end{array}$ & N of Items \\
\hline .956 & .958 & 15 \\
\hline
\end{tabular}

Tingkat Kepenting an

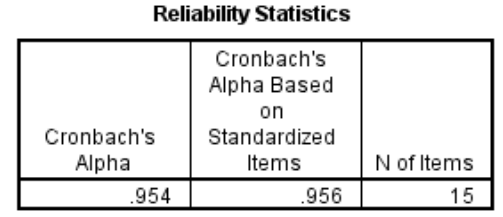

Tingkat Kinerja

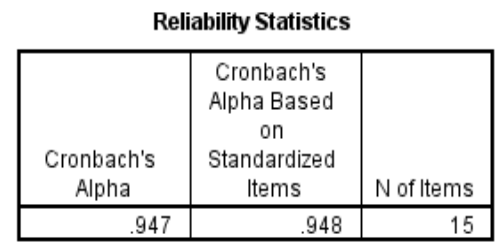

\subsection{Analisis Karakteristik Responden}

1. Jenis Kelamin

Berdasarkan hasil survey dari 75 responden dapat dilihat pada table jenis kelamin bahwa Lebih banyak mahasiswa berjenis kelamin perempuan yang mempunyai 
usaha bisnis yaitu sebesar $63 \%$. daripada lakilaki sebesar $37 \%$.

Tabel 7. Jenis Kelamin

\begin{tabular}{cccc}
\hline No & $\begin{array}{c}\text { Jenis } \\
\text { Kelamin }\end{array}$ & $\begin{array}{c}\text { Responden } \\
\text { (mahasiswa) }\end{array}$ & $\begin{array}{c}\text { Persentase } \\
(\%)\end{array}$ \\
\hline 1 & Laki-laki & 28 & 37 \\
2 & Perempuan & 47 & 63 \\
\hline & Jumlah & 75 & 100 \\
\hline
\end{tabular}

2. Usia

Untuk karakteristik usia dibagi menjadi 6 kelompok. Berdasarkan hasil survey dari 75 mahasiswa bahwa umur 19 tahun atau 25\% yang banyak mempunyai usaha bisnis. Dikarenakan mahasiswa sudah mendapat ilmu berbisnis dan mulai membutuhkan biaya lebih banyak.

Tabel 8. Usia

\begin{tabular}{llcc}
\hline No & Usia & $\begin{array}{c}\text { Responden } \\
\text { (mahasiswa) }\end{array}$ & $\begin{array}{c}\text { Persentase } \\
(\text { \%) }\end{array}$ \\
\hline 1 & $<18$ & 18 & 24 \\
2 & 19 & 19 & 25 \\
3 & 20 & 17 & 23 \\
4 & 21 & 15 & 20 \\
5 & 22 & 5 & 7 \\
6 & $>23$ & 1 & 1 \\
\hline & Jumlah & 75 & 100 \\
\hline
\end{tabular}

3. Marketplace yang digunakan

Dari hasil 75 responden bahwa customer paling banyak belanja online di shopee sebesar $57 \%$ dan peringkat kedua di Tokopedia sebesar $15 \%$. Dari dua marketplace tersebut merupakan peluang mahasiswa untuk meningkatkan penjualan produknya secara online di shopee dan tokopedia.

Tabel 9. Marketplace yang digunakan

\begin{tabular}{llcc}
\hline No & Marketplace & $\begin{array}{c}\text { Responden } \\
\text { (mahasiswa) }\end{array}$ & $\begin{array}{c}\text { Persentase } \\
(\%)\end{array}$ \\
\hline 1 & Lazada & 8 & 8 \\
2 & Blibli & 1 & 1 \\
3 & Shopee & 59 & 57 \\
4 & Tokopedia & 16 & 15 \\
5 & Bukalapak & 8 & 8 \\
6 & Jd.id & 2 & 2 \\
7 & Lain-lain : & & \\
& Social & & \\
& Media, OLX, & & 10 \\
& Whatsapp & 10 & 100 \\
\hline & Jumlah & 104 &
\end{tabular}

4. Metode pembayaran dalam transaksi

Metode pembayaran dalam transaksi yang banyak digunakan oleh pembeli yaitu Gerai Retail (Indomaret, alfamart, kantor pos,dll) sebesar $25 \%$ dikarenakan gerai indomaret dan alfamart sudah banyak disetiap wilayah.

Tabel 10. Metode pembayaran dalam transaksi

\begin{tabular}{clcc}
\hline No & $\begin{array}{l}\text { Metode } \\
\text { Pembayaran }\end{array}$ & $\begin{array}{c}\text { Responden } \\
\text { (mahasiswa) }\end{array}$ & $\begin{array}{c}\text { Persentase } \\
(\%)\end{array}$ \\
\hline 1 & $\begin{array}{l}\text { Transfer Bank } \\
2\end{array}$ & 22 & 19 \\
Transfer Virtual & $\begin{array}{l}\text { Account } \\
3\end{array}$ & 24 & 21 \\
$\begin{array}{l}\text { Pembayaran } \\
\text { Instan (Klik } \\
\text { BCA, Mandiri e- } \\
\text { cash, BRI e-Pay, } \\
\text { BNI, dll) }\end{array}$ & 14 & 12 \\
4 & $\begin{array}{l}\text { Kartu Kredit / } \\
\text { Debit Online / } \\
\text { Cicilan }\end{array}$ & 2 & 2 \\
5 & $\begin{array}{l}\text { Gerai Retail } \\
\text { (Indomaret, } \\
\text { Alfamaret, }\end{array}$ & & \\
Kantor pos, dll) & COD (Cash On & 29 & 25 \\
7 & $\begin{array}{l}\text { Delivery) } \\
\text { Lain-lain : Uang } \\
\text { Elektronik }\end{array}$ & 21 & 18 \\
\hline & Jumlah & 115 & 100 \\
\hline
\end{tabular}

5. Jasa pengiriman paket yang digunakan untuk transaksi

Dari hasil table 10 Data Jasa Pengiriman paket yang digunakan untuk transaksi kebanyakan konsumen memilih menggunakan JNE sebesar 33\% dan sicepat sebesar 23\% dikarenakan JNE sudah lama ada dan terpercaya.

Tabel 11. Jasa Pengiriman paket yang digunakan untuk transaksi

\begin{tabular}{clcc}
\hline No & $\begin{array}{l}\text { Jasa } \\
\text { pengiriman } \\
\text { paket }\end{array}$ & $\begin{array}{l}\text { Responden } \\
\text { (mahasiswa) }\end{array}$ & $\begin{array}{c}\text { Persentase } \\
(\%)\end{array}$ \\
\hline 1 & Gosend & 7 & 4 \\
2 & Grab & 5 & 3 \\
3 & JNE & 53 & 33 \\
4 & TIKI & 5 & 3 \\
5 & Sicepat & 37 & 23 \\
6 & AntarAja & 2 & 1 \\
7 & Wahana & 5 & 3 \\
8 & J\&T & 46 & 29 \\
\hline & Jumlah & 160 & 100 \\
\hline
\end{tabular}

\subsection{Hasil Analisis Impotance-Performance}

Hasil penjabaran kuadran Importance Performance Analysis didapat dari hasil tabulasi kuesioner rata-rata tingkat kinerja 
$(X)$ dan rata tingkat kepentingan $(Y)$ dapat dilihat pada diagram kartesius dibawah ini :

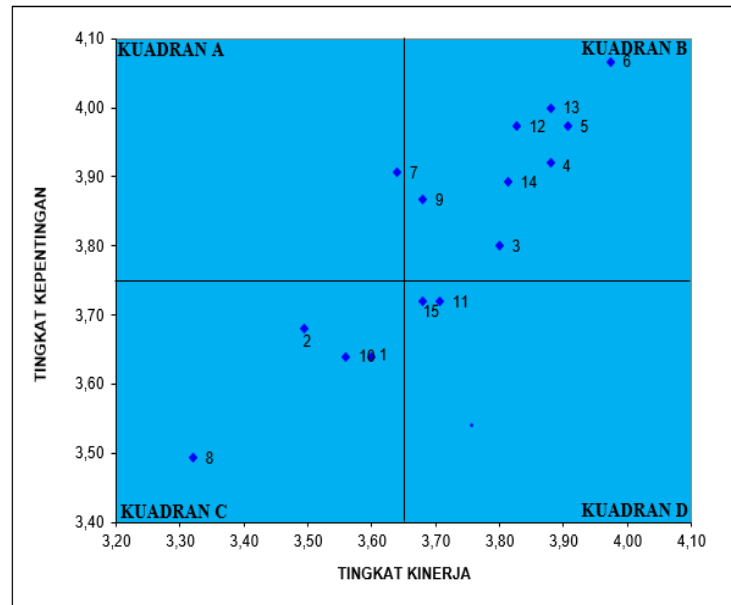

Gambar 3. Diagram Kartesius Peta Importance Performance Analysis

\subsection{Hasil Analisis Customer Satisfaction Index \\ Hasil nilai Customer Satisfaction} Index sebesar 74,49\% dimana nilai tersebut diantara $66 \%-80 \%$ yang berarti puas dengan perkembangan bisnis online sekarang.

Tabel 12 Hasil Nilai Hitung Customer Satisfaction Index (CSI)

\begin{tabular}{|c|c|c|c|c|}
\hline $\begin{array}{l}\text { No. } \\
\text { Atrib } \\
\text { ut }\end{array}$ & $\begin{array}{l}\text { Rata- } \\
\text { rata } \\
\text { Tingka } \\
\text { t } \\
\text { Harap } \\
\text { an }(Y)\end{array}$ & $\begin{array}{l}\text { Importan } \\
\text { ce } \\
\text { Weightin } \\
\text { g Factor } \\
\text { (persen) }\end{array}$ & $\begin{array}{l}\text { Rata- } \\
\text { rata } \\
\text { Tingk } \\
\text { at } \\
\text { Kinerj } \\
\text { a (X) } \\
\end{array}$ & $\begin{array}{l}\text { Weight } \\
\text { ed } \\
\text { Score } \\
\text { (WS) }\end{array}$ \\
\hline 1 & 3,56 & 6,27 & 3,60 & 0,23 \\
\hline 2 & 3,48 & 6,13 & 3,49 & 0,21 \\
\hline 3 & 3,84 & 6,77 & 3,80 & 0,26 \\
\hline 4 & 3,91 & 6,88 & 3,88 & 0,27 \\
\hline 5 & 3,89 & 6,86 & 3,91 & 0,27 \\
\hline 6 & 4,04 & 7,12 & 3,97 & 0,28 \\
\hline 7 & 3,83 & 6,74 & 3,64 & 0,25 \\
\hline 8 & 3,47 & 6,11 & 3,32 & 0,20 \\
\hline 9 & 3,81 & 6,72 & 3,68 & 0,25 \\
\hline 10 & 3,63 & 6,39 & 3,56 & 0,23 \\
\hline 11 & 3,69 & 6,51 & 3,71 & 0,24 \\
\hline 12 & 3,92 & 6,91 & 3,83 & 0,26 \\
\hline 13 & 3,97 & 7,00 & 3,88 & 0,27 \\
\hline 14 & 3,89 & 6,86 & 3,81 & 0,26 \\
\hline 15 & 3,81 & 6,72 & 3,68 & 0,25 \\
\hline Total & 56,75 & 100,00 & 3,72 & \\
\hline \multicolumn{4}{|c|}{ Weighted Total } & 3,72 \\
\hline \multicolumn{4}{|c|}{ Satisfaction Index } & $74,49 \%$ \\
\hline
\end{tabular}

\subsection{Implementasi Sistem}

Metode pengembangan sistem menggunakan prototyping yaitu sebuah metode yang melibatkan mahasiswa secara langsung dengan analisis dan perancangan sehingga peneliti dan mahasiswa dapat saling berinteraksi selama proses pembuatan sistem. Berdasarkan hasil Analisis Importance Performance Analysis dan Customer Satisfaction Index dapat mengidentifikasi kebutuhan system pada aplikasi penjualan online yang akan dibangun untuk memasarkan produk mahasiswa seperti tampilan produk, proses pemesanan barang, proses biaya kirim, proses pengecekan status pesanan barang dan proses yang lainnya.

Pada gambar 4 menampilan halaman home www.jelajahwarung.com berupa produk barang yang dijual oleh mahasiswa.

竞

\section{Atva Lidder TasRansel}

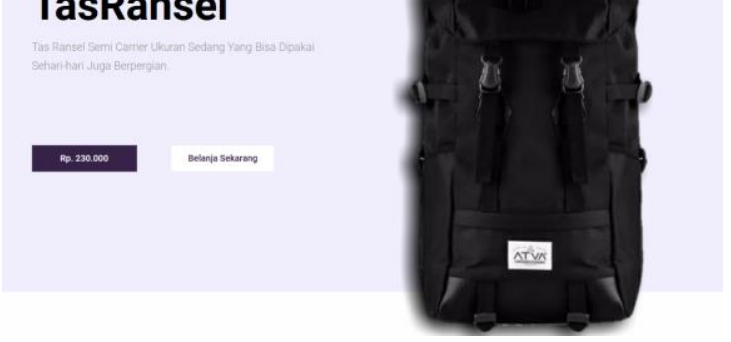

Gambar 4. Tampilan Halaman Home www.jelajahwarung.com

Sedangkan pada gambar 5 menjelaskan proses pengecekan status pesanan barang.

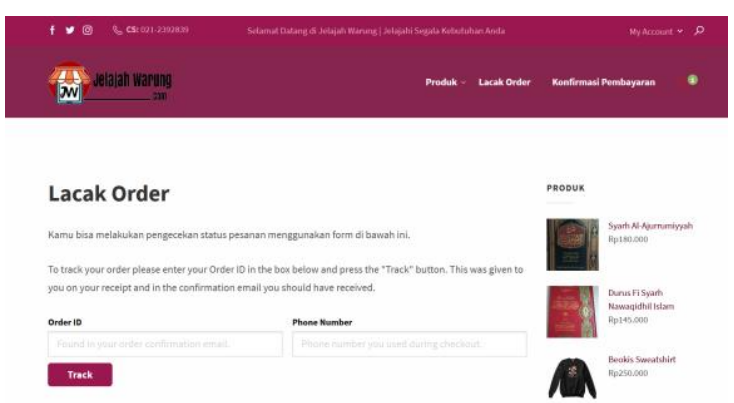

Gambar 5. Proses Pengecekan Status Pesanan 


\section{KESIMPULAN}

Kesimpulan dari hasil penelitian dan pembahasan mengenai Analisis Perkembangan Bisnis Online Mahasiswa Karawang Dengan Menggunakan Metode Customer Satisfaction Index (CSI) bahwa :

1. Dari 376 mahasiswa Universitas Singaperbangsa Karawang yang mengisi kuesioner hanya 78 mahasiswa yang mempunyai usaha bisnis atau sebesar $21 \%$ dan dominan berjenis kelamin perempuan sebesar $63 \%$.

2. Ada atribut prioritas utama dari diagram Kartesius Peta Importance Performance Analysis yang harus diterapkan kepada mahasiswa dalam menjalankan bisnis online yaitu Isi deskripsi produk di marketplace seperti kualitas produk, ukuran, bahan dan gambar harus sesuai dengan produknya.

3. Hasil dari perhitungan Customer Satisfaction Index didapat sebesar 74,49\% dimana mahasiswa puas dengan Bisnis yang sudah dilakukan dan diperkirakan akan meningkat setelah aplikasi penjualan online yang disediakan universitas mulai siap dioperasikan .

4. Berdasarkan Peringkat Weighting Score bahwa jaminan terkait keamanan dan kerahasian data saat berbelanja online sangat dibutuhkan pembeli karena data tersebut sangat privacy dan dapat mempengerahui kepercayaan pembeli terhadap bisnis online atau keputusan berbelanja online.

5. Aplikasi penjual online dibuat sebagai tempat bagi para mahasiswa yang ingin menjual produk barang secara online dan memudahkan mahasiswa mendapatkan pelanggan.

\section{DAFTAR PUSTAKA}

[1] Asosiasi Penyelenggara Jasa Internet Indonesia, "Hasil Survei Penetrasi dan Perilaku Pengguna Internet Indonesia 2018,"

https://apjii.or.id/content/read/39/410/ Hasil-Survei-Penetrasi-dan-PerilakuPengguna-Internet-Indonesia-2018, 2018. [Online]. Available: https://apjii.or.id/survei2017.

[Accessed: 18-Mar-2018].
[2] Badan Pusat Statistik Kabupaten Karawang, "Jumlah Penduduk Menurut Kecamatan di Kabupaten Karawang," https://karawangkab.bps.go.id/, 2016. [Online]. Available: https://karawangkab.bps.go.id/statictabl e/2016/10/27/55/jumlah-pendudukmenurut-kecamatan-di-kabupatenkarawang-2010-2014-dan-2015.html. [Accessed: 20-Mar-2018].

[3] S. Husna and A. Syukri, "Penerapan Customer Satisfaction Index (CSI) Dan Analisis Gap Pada Kualitas Pelayanan Trans Jogja," J. Ilm. Tek. Ind., vol. 13, no. 2, pp. 103-111, 2014.

[4] T. Chandra and D. Novia, "Procuratio: Jurnal Ilmiah Manajemen ANALYSIS OF SERVICE QUALITY AND CUSTOMER SATISFACTION USING CUSTOMER SATISFACTION INDEX (CSI) AND IMPORTANCE PERFORMANCE ANALYSIS (IPA) METHOD IN 'JAKARTA' OPTICAL PEKANBARU," vol. 7, no. 2, pp. 125139, 2019.

[5] A. Suhendra and D. W. I. Prasetyanto, "Kajian Tingkat Kepuasan Pengguna Trans Metro Bandung Koridor 2 Menggunakan Pendekatan ImportancePerformance Analysis," vol. 2, no. 2, pp. 59-70, 2016.

[6] R. W. Griffin and R. J. Ebert, Pengantar Bisnis. Jakarta: Prenhallindo, 2009.

[7] R. R. Situmeang, F. Ekonomi, U. Prima, and I. Medan, "DAMPAK BISNIS ONLINE DAN LAPANGAN PEKERJAAN TERHADAP PENINGKATAN PENDAPATAN MASYARAKAT ( STUDI KASUS JASA BISNIS ONLINE TRANSPORTASI GRAB DI KOTA MEDAN ) Pergerakan Ilmu Pengetahuan sangat menentukan berubah atau tidaknya peradaban manusia , dimana manusi," vol. 03 , no. September, pp. 319-335, 2018.

[8] S. Moertiningsih, "Dasar-Dasar Demografi," Lemb. Demogr. UI, 2010. 
[9] R. Nugraha, A. Harsono, and Adianto, "UsulanPeningkatan Kualitas Pelayanan Jasa pada Bengkel ' $X$ ' Berdasarkan Hasil Matrix ImportancePerformance Analysis (Studi kasus di Bengkel AHASS PD. Sumber Motor Karawang).," J. Online Inst. Teknol. Nas., vol. 1, no. 3, pp. 221-231, 2014.

[10] Sugiyono, STATISTIKA UNTUK PENELITIAN. 2010.

[11] E. Riadi, Statistika Penelitian (Analisis Manual Dan IBM SPSS). Yogyakarta: ANDI, 2016.

[12] W. V Sujarweni, "Metode dan Teknik Penelitian," Metod. Penelit., 2014.

[13] Sudarno, A. Rusgiyono, A. Hoyyi, and Listifadah, "Analisis Kualitas
Pelayanan Dan Pengendalian Kualitas Jasa Berdasarkan Persepsi Pengunjung," Media Stat., vol. 4, no. 1, pp. 33-45, 2011.

[14] S. Randall, E. Coast, and T. Leone, Cultural constructions of the concept of household in sample surveys, vol. 65, no. 2. 2011.

[15] A. Ferdinand, Metode Penelitian Manajemen. Semarang: Universitas Diponegoro, 2014.

[16] D. Fitriana, Florencia, J. U. Dwi, and Tanto, "Pengukuran Kepuasan Kontraktor Terhadap Kinerja Klien Pada Proyek Konstruksi Swasta," J. Karya Tek. Sipil, vol. 3, no. 1, pp. 283295, 2014. 